\title{
UPAYA MENINGKATKAN HASIL BELAJAR SISWA MELALUI MODEL PEMBELAJARAN KOOPERATIF TIPE THINK-PAIR-SHARE (TPS) DALAM MATERI TEKANAN KELAS VIII SMPN I KALIS
}

\author{
Iwan Ampriyadi \\ Guru SMPN 1 Kalis Kapuas Hulu \\ Email: iwanampriyadi@ymail.com
}

\begin{abstract}
The aim of this research is to find out the improvement of students learning output use cooperative learning teaching type think pair share (TPS). The form of research is the classroom action research consisting of two cycles with the steps of planning, action, observation and reflection. The subject of this research is students grade 8 of SMPN 1 Kalis. Quantitative data is taken from the pretest and postest, then is defined the average scores. The result of this research shows that there is an improvement of average of learning output is 33,75 in the first cycles and then the second cycles is 41,25. The increase of completion of the learning output is the first cycles is 90,63\%, while the second is 93,75\%. The observation result of the learning prosess showed that the students learning activities improved and it affected the students learning output. The learning process use cooperative learning model with think pair share type is expected to be used by physics teachers to teach.
\end{abstract}

Keys word: Learning output students, Cooperative type Think-PairShare (TPS), Pressure.

Ilmu Pengetahuan Alam (IPA) merupakan dasar pengetahuan yang mengungkapkan bagaimana fenomena alam terjadi. IPA mempunyai peranan penting bagi kehidupan manusia yakni sebagai bagian dari pengetahuan yang harus dimiliki dalam memasuki era globalisasi dan teknologi. Pembelajaran IPA di sekolah merupakan proses aktif, artinya pembelajaran IPA merupakan sesuatu yang dilakukan oleh siswa, bukan sesuatu yang dilakukan untuk siswa. Proses aktif berimplikasi terhadap aktivitas mental dan fisik. Tidak dapat dipungkiri bahwa pelajaran IPA merupakan bagian yang tidak dapat terpisahkan dari kehidupan manusia.
IPA adalah pengetahuan tentang fakta dan hukum-hukum yang didasarkan atas pengamatan dan disusun dalam suatu sistem yang teratur, di mana dalam proses pengamatan tersebut kita akan banyak berinteraksi dengan fenomena-fenomena yang terjadi dalam kehidupan kita sehari-hari. Banyak permasalahan sehari-hari yang dapat dipelajari dalam IPA. Belajar akan lebih bermakna jika siswa mengalami apa yang dipelajarinya, bukan hanya mengetahuinya. Salah satu cabang IPA adalah fisika, yaitu ilmu yang membahas gejala dan perilaku alam yang dapat diamati oleh manusia. Fisika merupakan suatu teori yang menerangkan gejala-gejala alam 
sesederhana-sederhananya dalam berusaha menemukan hubungan antara kenyataan-kenyataan, sehingga persyaratan-persyaratan dasar untuk memecahkan soal fisika adalah dengan mengamati gejala-gejala tersebut (Druxes, 1986: 3).

Pelajaran IPA di Sekolah Menengah Pertama (SMP) dan Madrasah Tsanawiyah (MTs) dalam Kurikulum Tingkat Satuan Pendidikan (KTSP) bertujuan agar peserta didik memiliki kemampuan antara lain mengembangkan pengetahuan dan pemahaman konsep-konsep IPA yang bermanfaat dan dapat diterapkan dalam kehidupan sehari-hari, mengembangkan keterampilan proses untuk menyelidiki alam sekitar, memecahkan masalah dan membuat keputusan (Depdiknas, 2006). Namun di sisi lain mata pelajaran IPA sering dianggap sebagai materi sulit dan menjadi hal yang menakutkan bagi sebagian siswa. Dengan diberlakukannya pendidikan yang berbasis KTSP ditingkat SMP diharapkan siswa bisa belajar dari kejadian-kejadian yang ada disekitarnya untuk lebih memahami konsep-konsep itu sendiri dan sangat berpengaruh dalam mendukung proses pembelajaran siswa di kelas.

Berdasarkan hasil wawancara dengan guru fisika kelas VIII diketahui bahwa salah satu materi yang dianggap sulit oleh siswa adalah materi tekanan. Di antara tiga kelas yaitu kelas VIII A, VIII B dan VIII C didapatkan rata-rata kelas paling rendah pada materi tekanan adalah kelas VIII B. Hal ini dapat dilihat dari nilai hasil ulangan harian materi tekanan yang diberikan oleh guru fisika pada siswa kelas VIII B sebagai berikut:

Tabel 1. Skor hasil ulangan materi tekanan kelas VIII B SMP Negeri 1 Kalis.

\begin{tabular}{cccc}
\hline No & Rentang Nilai & Jumlah Siswa & Persentase \\
\hline 1 & $<10$ & - & - \\
\hline 2 & $11-19$ & - & - \\
\hline 3 & $20-29$ & - & - \\
\hline 4 & $30-39$ & - & - \\
\hline 5 & $40-49$ & 6 & $23,08 \%$ \\
\hline 6 & $50-59$ & 9 & $34,62 \%$ \\
\hline Jumlah Siswa Yang Tidak Tuntas & $\mathbf{1 5}$ & $\mathbf{5 7 , 7 \%}$ \\
\hline 7 & $60-69$ & 6 & $23,08 \%$ \\
\hline 8 & $70-79$ & 4 & $15,38 \%$ \\
\hline 9 & $80-89$ & 1 & $3,84 \%$ \\
\hline 10 & $90-100$ & - & $\mathbf{4 2 , 3 \%}$ \\
\hline & Jumlah Siswa Yang Tuntas & $\mathbf{1 1}$ &
\end{tabular}

Masalah dalam penelitian ini adalah "Apakah Penerapan model Pembelajaran Kooperatif tipe ThinkPair-Share (TPS) dapat meningkatkan hasil belajar siswa pada materi tekanan di kelas VIII B SMP Negeri 1 Kalis ?’. Berdasarkan rumusan masalah di atas, maka alternatif cara pemecahan masalah tersebut adalah: mengetahui hasil belajar siswa pada materi tekanan sebelum pembelajaran digunakan pretest, mengetahui ada tidaknya peningkatan hasil belajar siswa menggunakan model pembelajaran kooperatif tipe TPS dengan 
membandingkan hasil pretest dengan posttest yang diberikan setiap selesai satu siklus kegiatan pembelajaran, serta mengetahui keunggulan dan hambatan model pembelajaran kooperatif tipe TPS diketahui dari lembar observasi.

Adapun manfaat yang dapat diambil dari penelitian tindakan kelas melalui model pembelajaran Kooperatif tipe Think-Pair-Share (TPS) adalah: dapat memperbaiki proses pembelajaran, dapat meningkatkan hasil belajar siswa, pembelajaran kooperatif sangat potensial untuk meningkatkan keterampilan berpikir dari siswa, model pembelajaran kooperatif ini memupuk kebiasaan siswa bekerjasama dalam belajar secara kolaboratif dengan teman-teman dalam kelompok, dan memberikan kontribusi kepada pihak sekolah untuk meningkatkan kinerjanya dalam pengelolaan pembelajaran terutama menemukan alternatif pemecahan masalah belajar mengajar guna meningkatkan mutu guru dan hasil belajar siswa.

\section{Metode}

Bentuk penelitian yang dilakukan adalah penelitian tindakan kelas. Penelitian tindakan kelas atau classroom action research yaitu penelitian yang dilakukan oleh guru di kelas atau di sekolah tempat mengajar, dengan penekanan pada penyempurnaan atau peningkatan praktik dan proses dalam pembelajaran (Susilo, 2007: 16). Penelitian ini dilakukan secara kolaborasi oleh peneliti dengan guru fisika di SMP Negeri 1 Kalis. Penelitian tindakan kelas ini dilakukan di kelas VIII SMP Negeri 1
Kalis. Dari ketiga kelas yang ada, kelas VIII B merupakan kelas dengan nilai rata-rata kelas paling rendah, sehingga menjadi subjek penelitian dengan jumlah siswa sebanyak 32 siswa. Pelaksanaan penelitian pada pelajaran fisika tentang materi tekanan.

Teknik pengumpul data dalam penelitian ini adalah teknik observasi. Menurut Steven (dalam Nazir 2009: 126) pengukuran adalah penetapan/pemberian angka terhadap objek atau fenomena menurut aturan tertentu. Pengukuran yang dimaksud dalam penelitian ini adalah pemberian skor hasil tes penelitian, baik awal maupum akhir sesuai dengan aturan yang telah ditetapkan secara logis. Lembar observasi digunakan untuk melihat dan menilai proses kegiatan belajar mengajar yang sedang berlangsung. Lembar observasi yang digunakan dalam penelitian ini adalah lembar observasi guru yang bertujuan untuk menilai dan melihat apakah guru sudah melakukan kegiatan pembelajaran sesuai dengan perangkat pembelajaran yang digunakan dan kesesuaian langkahlangkah dalam model pembelajaran kooperatif TPS. Lembar observasi siswa bertujuan untuk melihat dan menilai apakah siswa tersebut berperan aktif selama proses pembelajaran berlangsung dan apakah sudah sesuai dengan langkah-langkah model pembelajaran kooperatif tipe TPS.

Adapun prosedur atau langkah-langkah Penelitian Tindakan Kelas (PTK), seperti pada Gambar 1.

\section{Hasil dan Pembahasan}

Pengumpulan data selama penelitian diperoleh dua kelompok 


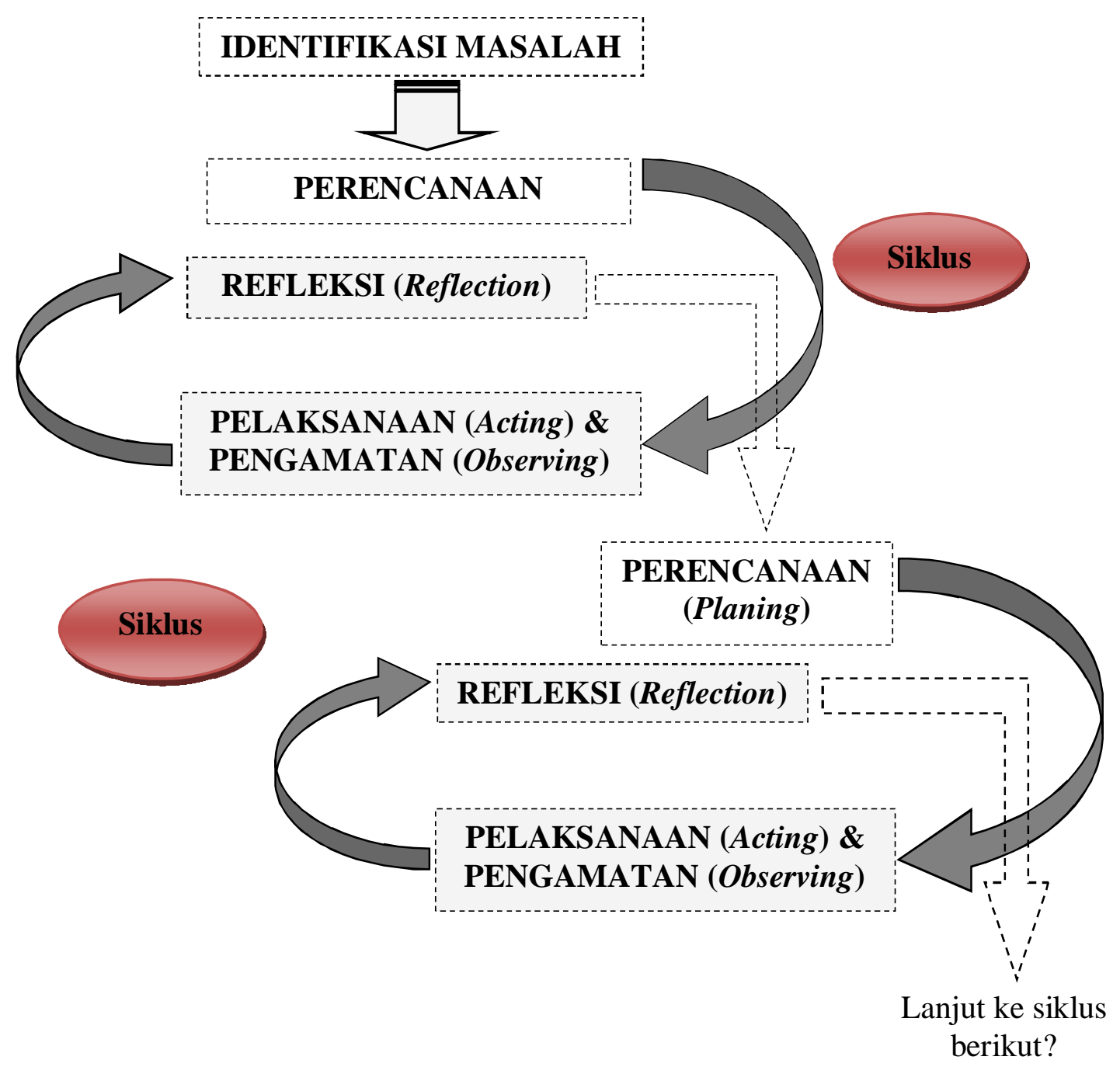

'Gambar 1. Model siklus Penelitian Tindakan Kelas diadaptasi dari Hopkins, (Tim Pelatih Proyek PGSM, 1999:7).

data, yaitu pre-test dan pos-test. Hasil tes dan perubahan skor dari hasil pretest dan pos-test dapat dilihat sebagai berikut Tes awal (pre-test) dilaksanakan dua kali yaitu tanggal 29 Maret 2014 untuk siklus I dan tanggal 30 April 2014 untuk siklus II.

Tes yang digunakan berupa tes pilihan ganda berjumlah 20 soal, 10 soal untuk pre-tes siklus I dan 10 soal untuk pre-tes siklus II dengan skor maksimal 100. Pemberian pre-test kepada siswa bertujuan untuk mengetahui bagaimana kemampuan awal siswa tentang materi tekanan sebelum diberikan perlakuan. Berdasarkan hasil pre-test siswa kelas VIIIB menunjukkan bahwa $100 \%$ siswa memperoleh skor di bawah 60 atau memperoleh skor di bawah kriteria ketuntasan minimal (KKM) dengan skor rata-rata 32,50 pada pretest siklus I dan 31,25 pada pre-test siklus II. Rata-rata tersebut menunjukkan bahwa skor siswa masih sangat rendah.

Pemberian post-test dilaksanakan pada akhir tiap siklus 
yang bertujuan untuk mengetahui hasil belajar siswa setelah diberi perlakuan menggunakan model pembelajaran kooperatif Think-PairShare (TPS). Rata-rata hasil posttest siswa pada siklus I adalah 66,25 dengan skor maksimum yang diperoleh siswa yaitu 90. Ditinjau dari Kriteria Ketuntasan Minimal (KKM) yang ditetapkan oleh sekolah yaitu sebesar 60, hasil pre-test siswa yang semula $100 \%$ siswa tidak tuntas meningkat menjadi 29 orang siswa tuntas pada hasil post-test siklus I atau terdapat peningkatan ketuntasan hasil belajar pada siklus I sebesar 90,63\%. Sedangkan pada siklus II, rata-rata post-test siswa yaitu 72,50 dengan skor maksimum 100. Hasil pre-test siswa siklus II yang semula semua siswa tidak tuntas meningkat menjadi 30 orang siswa tuntas pada hasil post-test siklus II atau terdapat peningkatan ketuntasan hasil belajar sebesar $93.75 \%$. Jadi skor rata-rata tersebut menunjukkan bahwa hasil belajar siswa kelas VIIIB SMP Negeri 1 Kalis terjadi peningkatan. Untuk lebih jelasnya pre-test dan postes dapat dilihat Tabel 2.

Tabel 2. Rekapitulasi Skor Pre-Test dan Pos-Test.

\begin{tabular}{|c|c|c|c|c|c|c|}
\hline & \multicolumn{2}{|c|}{ Siklus I } & \multirow{2}{*}{$\begin{array}{l}\text { Peningkatan } \\
\text { hasil belajar } \\
\text { siklus I }\end{array}$} & \multicolumn{2}{|c|}{ Siklus II } & \multirow{2}{*}{$\begin{array}{l}\text { Peningkatan } \\
\text { hasil belajar } \\
\text { siklus II }\end{array}$} \\
\hline & PreTest & PosTest & & PreTest & PosTest & \\
\hline $\begin{array}{l}\text { Skor } \\
\text { rata-rata }\end{array}$ & 32,50 & 66,25 & 33,75 & 31,25 & 72.50 & 41,25 \\
\hline $\begin{array}{l}\text { Ketuntas } \\
\text { an rata- } \\
\text { rata }\end{array}$ & $0 \%$ & $90,63 \%$ & $90,63 \%$ & $0 \%$ & $93,75 \%$ & $93,75 \%$ \\
\hline
\end{tabular}

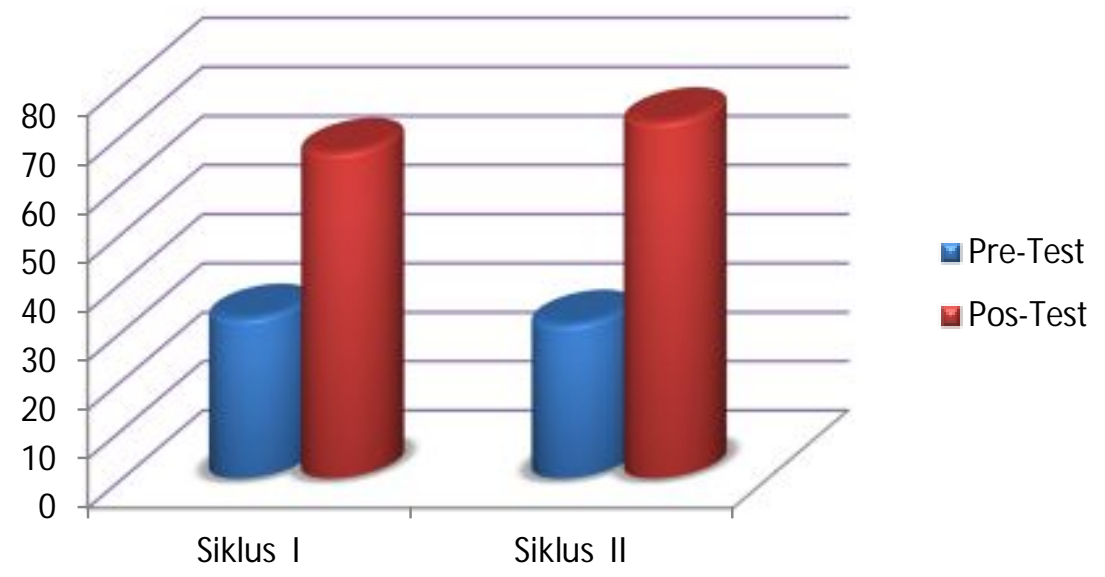

Gambar 2. Grafik perbandingan skor rata-rata pre-test dan pos-test.

Berdasarkan hasil observasi dapat diketahui aktivitas belajar siswa sudah baik dan hasil belajar siswa meningkat dibandingkan siklus I. Di siklus II ini, guru lebih membimbing siswa dalam menjalankan tahap-tahap dalam pembelajaran, sehingga siswa benar-benar telah hafal dalam tahapan model pembelajaran kooperatif tipe TPS ini. Guru memberikan beberapa contoh tekanan padat zat padat, cair dan gas dalam kehidupan sehari-hari 
dan memberikan pertanyaan umpan balik kepada siswa. Hal ini membuat siswa semakin termotivasi dalam belajar karena contoh yang diberikan berkaitan dengan kehidupan disekeliling mereka sehingga mereka menjadi paham tentang materi yang diajarkan. Namun demikian, di siklus II ini ada beberapa siswa yang memperoleh skor tetap dibandingkan dengan siklus I, dan ada pula yang nilainya menurun. Ini disebabkan oleh pemahaman siswa yang kurang tentang materi dan minat siswa dalam belajar yang tidak selalu baik sehingga berpengaruh pada hasil belajarnya. Namun, pada siklus II ini siswa sudah aktif dalam bertanya jawab memberikan contoh aplikasi dan dampak akibat tekanan yang terjadi di kehidupan sehari-hari.

Hasil belajar siswa dan lembar observasi aktivitas siswa terlihat keunggulan model pembelajaran kooperatif tipe TPS dapat meningkatkan hasil belajar siswa, karena model ini cocok dengan materi tekanan yang diajarkan, dalam proses pembelajaran siswa termotivasi untuk memberikan perhatiannya pada materi yang sedang mereka pelajari serta siswa dapat terlibat langsung dalam tahapan-tahapan yang digunakan dalam pembelajaran sehingga keterampilan berpikir siswa menjadi meningkat yakni dimana awalnya siswa itu mengerjakan berpikir sendiri, kemudian diberikan kesempatan untuk berpasangan dengan teman sebangkunya mendiskusikan suatu masalah yang dihadapinya, dan kemudian berbagi kepada teman-teman sekelas mengenai masalah-masalah yang dihadapi tersebut. Disini siswa beradu argumen dengan siswa lainnya mengenai jawaban dari soal yang diberikan, siswa bertanggung jawab terhadap jawaban yang disampaikan. Dengan ini pengetahuan siswa akan terekam dengan sendirinya, siswa akan mudah mengingat pelajaran yang telah disampaikan, sehingga pada saat diberikan tes kembali siswa akan mudah mengerjakannya, hasil belajar siswa menjadi meningkat, siswa menjadi lebih aktif, dan memenuhi Kriteria Ketuntasan Minimal (KKM) nya.

\section{Simpulan dan Saran}

Berdasarkan analisis data dan pembahasan yang telah dilakukan dapat disimpulkan bahwa penerapan model pembelajaran Kooperatif tipe Think-Pair-Share (TPS) dapat meningkatkan hasil belajar siswa kelas VIIIB SMP Negeri 1 Kalis pada materi tekanan. Secara terperinci kesimpulan dalam penelitian ini dapat dijabarkan sebagai berikut:

1. Pengetahuan awal (pre-test) siswa kelas VIIIB SMP SMP Negeri 1 Kalis sebelum diajarkan dengan model pembelajaran Kooperatif tipe Think-Pair-Share (TPS) pada siklus I dengan sub materi pegertian tekanan, tekanan zat padat dan tekanan zat cair diperoleh skor rata-rata pre-test 32,50. Pada siklus II dengan materi hukum Archimedes dan tekanan udara diperoleh skor rata-rata pretest 31,25. Skor rata-rata ini masih di bawah Kriteria Ketuntasan Minimal (KKM).

2. Hasil belajar siswa (post-test) setelah diajarkan dengan model pembelajaran Kooperatif tipe Think-Pair-Share (TPS) pada siklus I dengan materi pegertian tekanan, tekanan zat padat dan 
tekanan zat cair terjadi peningkatan skor rata-rata menjadi 66,25 atau sebesar 90,63\% siswa sudah mencapai Kriteria Ketuntasan Minimal (KKM). Sedangkan hasil belajar siswa (post-test) pada siklus II dengan materi hukum Archimedes dan tekanan udara juga terjadi peningkatan skor rata-rata yaitu menjadi 72,50 atau sebesar 93,75\% siswa mencapai Kriteria Ketuntasan Minimal (KKM).

3. Keunggulan pembelajaran model Kooperatif tipe Think-Pair-Share (TPS) adalah dapat meningkatkan hasil belajar siswa pada materi Tekanan di kelas VIIIB SMP Negeri 1 Kalis, karena model ini cocok dengan materi yang diajarkan, dalam proses pembelajaran siswa termotivasi dalam belajar sehingga berpengaruh pada hasil belajar yang baik.

4. Hambatan dalam pembelajaran model Kooperatif tipe Think-PairShare (TPS) yaitu perlunya pengaturan waktu dan pengolahan kelas yang tepat oleh guru dalam pelaksanaan pembelajaran sehingga waktu yang ada tidak terbuang sia-sia.

\section{Daftar Rujukan}

Abdullah, Mikrajuddin. (2007). IPA Fisika SMP dan MTs Untuk Kelas VIII. Jakarta: Esis

Arikunto, S. (2008). Penelitian Tindakan Kelas. Jakarta: Bumi Aksara.

Budiningsih, Asri. (2008). Belajar dan Mengajar. Jakarta: Rineka Cipta
Druxes, Herbert. (1986). Kompendum

Didaktik Fisika Alih Bahasa

Oleh Yuhilza Hanum.

Bandung : Remadja Karya

Isjoni. (2007). Cooperative Learning. Bandung : Alfabeta

Iskandar. (2009). Penelitian Tindakan

Kelas. Jakarta : Gaung Persada Press.

Kamajaya, Tedy Wibowo.( 2007). Inspirasi Sains pelajaran IPA Terpadu untuk SMP Kelas VIII. Jakarta : Ganeca Exact.

Kanginan, Marthen. (2007). IPA FISIKA Untuk SMP Kelas VIII. Jakarta : Erlangga

Lie, Anita. (2004). Cooperatif Learning. Jakarta: Grasindo

Mangunwiyoto, Widagdo. (2007). Pokok-Pokok FISIKA SMP Untuk Kelas VIII. Jakarta : Erlangga

Nawawi, H. (2005). Metode Penelitian Bidang Sosial. Yogyakarta : Gajahmada Universitas Press.

Nazir, Moh. (2009). Metode Penelitian. Bogor : Ghalia Indonesia

Ngalim Purwanto. (1990). Psikologi Pendidikan. Bandung: Remaja Rosdakarya

Oktavia, Eva. (2009). Meningkatkan hasil belajar siswa dengan menggunakan model kooperatif teknik Think-PairShare (TPS) berbantuan LKS Pada Materi Hukum Newton Di Kelas VIII SMP Negeri 03 
53 Jurnal Pendidikan Matematika dan IPA Vol. 5. No. 1. Januari 2014:46-53

Sukadana. Skripsi. Pontianak: FKIP UNTAN.

Purwanto, Budi. (2006). Sains Fisika 2 Konsep dan Penerapannya. Solo : Tiga serangkai

Rahmini S, Agus R. (2007). Ilmu Pengetahuan Alam FISIKA 2 untuk SMP/MTs kelas VIII. Semarang : Aneka ilmu

Subyantoro. (2009). Penelitian Tindakan Kelas. Semarang: Badan Penerbit Universitas Diponegoro Semarang

Sudarwanto, Gunawan. (2010). Peningkatan aktivitas dan hasil belajar akuntansi Manajemen dengan pendekatan kooperatif (thinkpaireshare) Mahasiswa pendidikan akuntansi tahun 2005-2006. (online). (http://blog. unila. ac. id/radengunawans/files/2010/0 7/jurnal-2005-2006pdf, dikunjungi 16 Februari 2012)

Sudijono, Anas. (2009). Pengantar Evaluasi Pendidikan. Jakarta : PT Raja Grafindo Persada
Sugiyono. (2006). Metode Penelitian Pendidikan. Bandung : CV Alfabeta.

Sumarwan. (2007). IPA SMP Untuk Kelas VIII. Jakarta : Erlangga

Suparno, Paul. (2002). Reformasi Pendidikan. Yogyakarta : Kanisius

Suprijono, Agus. (2009). Cooperative Learning. Yogyakarta: Pustaka Pelajar

Susilo. (2007). Panduan Penelitian Tindakan Kelas. Yogyakarta: Pustaka Book Publisher

Surya Y, Raditya P.( 2009). Mahir Fisika SMP/MTs 1,2 dan 3. Jakarta : Kendi Mas Media

Tim Pelatih Proyek PGSM. 1999. Penelitian Tindakan Kelas (Classroom Action Research). Jakarta: Debdikbud.

Trianto. (2007). Model-model Pembelajaran Inovatif Berorientasi Kontruktivistik. Jakarta : Prestasi Pustaka Publisher.

Wardhani. (2007). Penelitian Tindakan Kelas. Jakarta : Universitas Terbuka. 